\title{
Üsteleyici Hasta
}

\section{Demanding Patient}

\author{
Erol Ozmen ${ }^{\star}$, Erol Ozan
}

Manisa Celal Bayar Üniversitesi Tıp Fakültesi Psikiyatri Anabilim Dalı

\begin{abstract}
ÖZET
Doktorlar günlük uygulamalarında zor hasta olarak nitelendirdikleri çok sayıda hasta ile karşılaşmaktadırlar. Hekimlerin zor hasta olarak nitelendirdikleri bu hastalar1 sınıflandırma konusunda belli bir görüş birliği bulunmamaktadır. Ancak bazı işlem ve incelemeleri yapması ya da yaptırması için doktorları zorlayan 'ssarcı', 'talepkâr' ya da 'üsteleyici' hastaları bir grup olarak ele almak mümkün gibi görünmektedir. Bu yazıda bu hastalar 'ïsteleyici hasta' başlığı altında ele alınmaktadır. Üsteleyici davranıșta doktorun açıklamalarına karșın hastanın ısrarcı olması, inanmaz bir yaklaşım göstermesi, her türlü açıklamaya karşın isteğini yineleyici bir şekilde gündeme getirmesi ve zorlayıcı bir yaklaşım içinde olması söz konusudur. Üsteleyici davranışlar çok değişik nedenlerle ortaya çıkabilmektedir. Üsteleyici davranışın ortaya çıkmasında en belirleyici etmenler hastanın kişilik yapısı ve stresle baş etme gücüdür. Ancak doktorun davranışları ya da görünümü de üsteleyici davranışı arttırabilmektedir. Üsteleyici davranış gösteren bir hasta ile karşılaştığında doktorun bu davranışla baş edip edemediği konunun diğer boyutunu oluşturmaktadır. Üsteleyici hasta ile baş etmeye çalışan doktorlar kendi kişilik özelliklerini ve hastasının biyopsikososyal özelliklerini dikkate alarak hastasına yaklaşmalıdır.
\end{abstract}

Anahtar Kelimeler: Üsteleyici hasta, Zor hasta, Doktorhasta etkileşimi

\section{Giriş}

Her türlü sağl1k hizmeti sunumunda sağl1k çalışanları ile hasta ve/veya yakınları arasında çatışma yaşanabildiği ve sağlık çalışanlarının bu çatışmalardan çoğu zaman hasta ve/veya yakınlarını sorumlu tuttukları, onları suçladıkları görülmektedir. Doktorların sorun yaşadıkları hastalara yakıştırdıkları ifadelerden birisi de 'zor hasta'dır. Ancak birçok doktor tarafindan kullanılıyor olmasına karşın 'zor hasta' tanımlanmasi ve siniflandirilması pek kolay olmayan bir kavramdir. Bir doktorun zor hasta olarak tanımladı̆̆ı bir hastanın başka bir doktor

\begin{abstract}
Physicians encounter many patients in their daily practice often described as difficult patient. However, there is no specific consensus on the classification of these patients which physicians describe as difficult patient. However, it seems possible to describe patients as 'insistent', 'demanding' or 'persistent' when they force the physicians or have the physicians force other medical staff to conduct some operations and investigations. Such patients described in this paper are listed under the heading of 'demanding patient'. In demanding behavior, the patient's insistence, distrustful approach, and repeated requests continues despite the physician's explanation. Demanding behavior can occur for a variety of reasons. The most significant factors in the occurrence of demanding behavior are the patient's personality traits and ability to cope with stress. However, the physician's appearance and behavior may also increase the patients' demanding behavior. Another dimension of the issue is the coping ability of the physician when faced demanding patient. Physicians who try to cope with demanding patients should approach their patients by taking into account their own personality traits and the patient's biopsychosocial characteristics.
\end{abstract}

Key Words: Demanding patient, Difficult patient, Doctor-patient interaction

tarafindan bazen aynı şekilde değerlendirilmiyor olması, hastaların farklı zamanlarda farklı davranışlar sergileyebilmeleri ve doktorların bir zaman katlanabildikleri hastalara bașka bir zaman katlanamiyor olmalar1 zor hasta tanımın neredeyse olanaksızlaştırmaktadır. Diğer yandan zor hasta kavramının damgalayıcı olduğu ve ilişkide yaşanan sorunun sorumluluğunu bütünüyle hastaya yüklediği, bu nedenle 'zor hasta' yerine 'zor etkileşim' gibi farklı bir ifadenin kullanılması daha doğru görünmektedir.

Literatür incelendiğinde ülkemizde tanı, tedavi ve bakım süreçlerinde sağlık çalışanlarına zorluk ç1karan hastaların ülkemizde 'zor hasta' $(1,2)$, 
'huysuz hasta' (3) olarak nitelendirildiği görülmektedir. Ülkemizde zor hastalar ile ilgili iki araştırmaya rastlanmıştır. Ancak bu araştırmaların örneklem seçimi elde edilen bulguların doktorlara uyarlanmasını mümkün k1lmamaktadır $(1,3)$.

Zor hastaların genel kabul gören bir siniflaması bulunmamakla birlikte bazı işlem ve incelemeleri yapması ya da yaptırması için doktorları zorlayan hastalar bir grup olarak tanımlanabilecek nitelikler taşımaktadır. İngilizce yayınlarda genellikle 'demanding patient' olarak tanımlanan bu zor hasta grubunu Türkçe 'de 'üsteleyici hasta', '1srarc1 hasta' ya da 'talepkâr hasta' olarak karşılamak mümkün gibi görünmektedir. Bu yazıda daha kapsayıc1 olduğu düşünülerek 'üsteleyici hasta' terimi kullanılacaktır.

Üsteleyici hasta konusunu incelerken öncelikle üsteleyici hasta kavramının tanımlanması ve sınırlarının çizilmesi gerekmektedir. Nitekim yakın zamanda Back (2015) 'üsteleyici hasta miti' başlıklı yazısında sağlık çalışanlarının kendilerinden çeşitli isteklerde bulunan tüm hastaları üsteleyici olarak niteleme eğiliminde olduklarını tartışmaktadır (4). Ancak görüşünü ve beklentisini söyleyen, doktordan bazı işlem ve incelemelerin yapılması isteğinde bulunan her hasta üsteleyici olarak nitelendirilmemelidir. Nitekim hastaların aklını kurcalayan konuları doktoruna söylemesi ya da sorması hastanın daha iyi anlaşılmasını ve olası bazı çaba ve girişimlerinin doktor tarafından daha iyi anlaşılmasını sağlamaktadır. Üsteleyici davranışta doktorun açıklamalarına karşın hastanın 1srarc1 olması, inanmaz bir yaklaşım göstermesi, her türlü açıklamaya karşın isteğini yineleyici bir şekilde gündeme getirmesi ve zorlayıc1 bir yaklaşım içinde olması söz konusudur.

Sağlık çalışanları hastaların eskisine göre daha talepkâr, 1srarc1 ve buyurgan olduğunu düşünmektedirler. $\mathrm{Bu}$ noktada vurgulanması gereken konulardan birisi de talepkâr olmanin yalnız sağlık hizmetleri ile ilgili olmadığıdır. Günümüzde her alanda müsterilerin daha talepkâr olduğu düşünülmektedir (5).

\section{Altta Yatan Nedenler}

Tüm üsteleyici hastalar için geçerli tek bir altta yatan neden belirlenmesi mümkün değildir. Her üsteleyici kişi için o kişiye özgü bir ya da birkaç neden söz konusu olmakla birlikte aynı üsteleyici kişinin farklı doktorlarla ilişkilerinde farklı nedenlerle doktoru zorlayan davranışlar göstermesi de olasıdır.
Üsteleyici bir davranışla karşılaşıldığında mutlaka açığa kavuşturulması gereken konulardan birisi de bunun hastanın her zamanki davranışı mi yoksa onda pek sık görülmeyen bir davranış mı olduğunu belirlemektir. Her zamanki davranışı ise daha kişilik yapısı ile ilgili, zaman zaman gösterdiği bir davranış ise daha güncel konular ile ilgili nedenler akla gelmelidir.

Aşağıda üsteleyici davranışa yol açabilen nedenler sıralanmıştır:

Stres ile baş etme: Hastaların sağlık çalışanlarını zorlayan ya da öfkelendiren davranışları çoğu zaman hastanın yaşadığı stres ile baş etme çabalarının yansımasıdır. Sağlık hizmeti alırken yaşayacakları ve hastalık (ya da hastalık tehdidi) hemen her insanın kayg1 ve korku yaşamasına neden olur. Birçok hasta yaşadıkları duyguya katlanarak, duyguyu yatıştırarak ve uyumlu tepki göstererek bu duygularla başarılı biçimde baş ederken bazı hastalar baş edemez ve uyumsuz davranışlar gösterirler. Nitekim üsteleyici davranışlar da stresle baş etme çabasıdır. Bu nedenle üsteleyen bir hasta ile karşılaşıldığında onu zorlayan etmenlerin belirlenmesi, ilişki ve iletişim sürecinde dikkate alınması gerekmektedir.

Kişilik bozukluğu: İnsan davranışını belirleyen en önemli etmenlerin başında kişilik özellikleri gelmektedir. Ancak üsteleyici davranışın yalnız belli bir kişilik yapısında ortaya çıkmadığı her kişilik yapısının kendine özgü üsteleyici davranış gösterdiği unutulmamalıdır. Diğer yandan baş etmekte zorlandığ1 hasta ve/veya yakınları ile karşılaştı̆ı̆ında doktorların aklına genellikle hastada bir kişilik bozukluğu olduğu gelse de bu oran sanıldığ1 kadar yüksek değildir. Schafer ve Nowlis'in yaptı̆̆ 1 bir araştırmada (1998) aile hekimlerinin zor hasta olarak nitelendirdikleri 22 hastadan 7'sinde bir kişilik bozukluğu olduğu belirlenmiştir (6).

Beklenti düzeyi: Tüm kişilerarası ilişkilerde olduğu gibi hasta-doktor ilişkisinde de beklenti düzeyi ne kadar yüksekse ya da beklentiler ne kadar gerçeklikle uyuşmuyorsa ilişkide sorun yaşanma olasılığı da o kadar artar.

Beklenti denildiğinde çoğu zaman gözlenebilen ve farkında olunabilen beklentiler akla gelir. Fakat beklentilerin yalnız farkında olunan ya da görünen ile sınırlı olmayabileceği, bilinçdışı nitelikler taşıyan ve hastanın ya da doktorun çoğu zaman farkına varamadığı beklentilerin de olacağ1 unutulmamalıdır.

İncelendiğinde üsteleyici hastaların genellikle gerçekliğe uymayan beklentilerinin olduğu görülür. Bu beklentilerin bilinçdışı kaynağı ne kadar köklü 
ise bu beklentilerin karşılanması o kadar mümkün değildir. Geleneksel hasta-doktor ilişkisi hastada doktordan yapabileceğinin daha ötesinde beklentiler oluşturarak üsteleyici davranış1 arttırmaktadir.

Duygular: Hastalıklar ve hasta-doktor ilişkisi her insanda çeşitli duygular yaratır. Bu duygular bazen hastalığın yaratabileceği gerçek tehdidin çok ötesinde ve şiddetli olabilmektedir. Yatıştıramadığı, baş edemediği ya da katlanamadığı duygular hastalarin uyumsuz davranmalarina yol açar. Üsteleyici davranışa yol açan belli bir duygu bulunmamakla birlikte etkinleşen duygular hastanin daha 1srarc1 olmasina neden olabilmektedir.

Deneyimler: Geçmişte kendisi ya da bir yakını doktor hatas olarak nitelendirilen bir sağlık sorunu yaşamış olan hastalar sağlık hizmeti alırken daha tepkisel olmaktadirlar. Böyle bir durumda hastaların üsteleyici davranma olasıllğ 1 artmaktadır.

Yanlış bilgiler: Hastalıklar ve sağlık hizmetleri ile ilgili bilgileri hastaların davranışlarını etkilemektedir. Günümüzde bilgiye ulaşımın kolaylaşmış olmasına karşın ulaşılan bilginin doğru olup olmadığ1 ve hasta tarafindan doğru yorumlanıyor olup olmadığ1 önemli bir sorun oluşturmuştur. Hastalar arama motorlarını kullanarak elde ettiği bilgilerden ve televizyon dizilerinde yansıtılan sağlık hizmeti sunumlarından etkilenerek üsteleyici davranışlar gösterebilmektedirler.

Psikolojik gereksinimler: İnsan davranışının oluşumunda psikolojik gereksinimler önemli bir yer tutmaktadır. Üsteleyici davranış1 oluşturabilecek psikolojik gereksinimleri şu şekilde sıralayabiliriz: (a) Çocukluğunda hak ettiği sevgi ve ilgiyi görmeyen kişilerde oluşan sevgi ve ilgi açlı̆̆1, karşılanması mümkün olmayan ilgi-sevgi görme açlı̆̆1 yaratabilir. (b)Anne ve/veya babas1 tarafından 'özel' bir insanmış gibi yetiştirilenler aynı davranışı doktorlardan da bekleyebilirler. (c) Üsteleyici davranış utanç, suçluluk ve kaygı gibi duyguları yatıştırma işlevi görebilir. Bunun en tipik örneği suçluluk duygusu içinde olan hasta yakınlarında görülür. (d) 'Ağlamayan çocuğa meme vermezler' deyiminde ifade edildiği gibi çocukluğunda gereksinimlerini ancak diğer insanları zorlayarak elde edenler bu davranışlarını erişkinlikte de sürdürür sürekli 'ağlar'lar.

Doktorun davranışları: Her insanın davranışının karşısındaki insanı etkilediği gibi doktorun davranışları ve görünümü de hastayı etkiler. Örneğin yorgun ve bezgin bir doktor, hastada doktorun kendisiyle ilgilenmeyeceği izlenimi yaratabilir. Yine beklentileri ve psikolojik gereksinimleri karşılanmadığında yatkın hastaların kolayca üsteleyici bir yaklaşım sergileyebilmeleri diğer bir örnek olarak verilebilir.

"Müşteri hasta" ya da "tüketici hasta" anlayışı: Günümüzde giderek artan hasta odaklı yaklaşım beraberinde hastanın bir tüketici ya da müşteri olarak ele alınması anlayışını da getirmiştir. Bu anlayışın hastaların davranışlarını nasıl etkileyeceği konusu henüz belirsizdir $(7,8)$. Ancak muhtemelen üsteleyici davranışları arttıracak ya da şiddetlendirecektir.

\section{Klinik Görünüm}

Genel olarak üsteleyici hasta 'israrla doktorun yaptırmayı düşünmediği incelemelerin yapılmasını ve uygun görmediği ilaçları ya da tedavileri uygulamasını isteyen ya da kendisiyle daha çok ilgilenilmesini bekleyen hasta' olarak tanımlanabilir. Hasta gereksindiği hizmetin doktor ve sağlık sistemi tarafindan verilmeyeceği kanısı içindedir (9).

Fakat kararlı ve özgüvenli kişilik yapısının yansimasi olarak isteklerde bulunan ya da doktoru kandırmaya çalışan hastaların gerçek üsteleyici hastalardan ayrilmasi gerekmektedir. Baz1 hastalar kararlı ve özgüvenli bir kişiliğin yansıması olarak haklarını sonuna kadar arar ya da bildiklerinde 1srarc1 olurlar. Aynı şekilde çıkar elde etmek amacıyla doktoru kandırmaya çalışan temaruz eden (hasta taklidi yapan) olguların da üsteleyici davranıştan ayrılması gerekir. Yine madde bağımlılığ1 olan hastalar hasta rolü oynayarak doktora gidebilirler. Örneğin ağr1 için 1srarla narkotik analjezik isteyen hasta bağımlı olabilir.

Gerçek üsteleyici hastaların davranışları psikolojik gereksinimlerden kaynaklanır. Üsteleyici hastalarda sık görülen davranış örnekleri:

- Sürekli kendisi ile ilgilenilmesini sağlama çabası ya da ilgilenilmesini isteme

- Görüşmeyi uzatmaya çalışma

- Randevu günü dişında muayeneye gelme ya da gelme talebi

- Doktora sik sik telefonla ulaşma çabası

- Israrla tıbbi olarak gerekmeyen inceleme isteme

- Endikasyon yokken doktordan bazı ilaçları yazmasin isteme

Üsteleyici hastaların tümünde aynı davranış kalıpları görülmez. Üsteleyici davranışın klinik görünümünü hastaların kişilik özellikleri belirler. Baz1 üsteleyici insanlar ne yapilırsa yapılsın bir 
türlü memnun olmazlar. Başka bir deyişle bir doymazlık içinde sürekli isteme vardır. Ancak 1srarlı biçimde istemenin tarzı önemlidir. Sırnaşık isteme ile zorlay1c1 ve tehdit edici isteme farklı anlamlar taşır. Hasta doktorun gerekli incelemeleri yapmadığını ve kendisine doğru tanı koymadığını düşünüyor olabilir. Tez canlı insanlar her şeyin bir an önce tamamlanması beklentisi içindedirler. Beklemek ve katlanmak bu insanlara dayanılmaz gelir.

Kişilik özellikleri dikkate alındığında ortaya çıkabilecek davranış örüntüleri aşağıda ele alınmıştır:

Borderline üsteleyici: Borderline kişilik özellikleri olan insanlar kolayca ihmal edildikleri duygusuna kap1lırlar. İhmal edildikleri, yakınlık görmedikleri ya da onaylanmadikları hissine kapıldıklarında bunları elde etmek için ellerinden geleni yaparlar.

Obsesif üsteleyici: Obsesif kişilik yapısına sahip olanlar mükemmeliyetçidirler. Olup biteni yalnız kendi pencerelerinden görür; tanı ve tedavi süreçlerinin denetimini ellerinde tutmak isterler. Mükemmeliyetçi yapıları nedeniyle kolayca 'eksik bir sey kalmasin' ve 'bir yanlishle olmasin' düşüncelerine kapılırlar. Diğer yandan doktorun tan1 ve tedavi sürecindeki istemleri hastada yaşamının denetimini yitirdiği hissi yaratır. Bu his hastanın inatçı davranışlar göstermesine doktorla çekişmesine neden olabilir.

Narsist üsteleyici: Narsistik kişilik yapısına sahip olanlar her şeyin en iyisini hak ettikleri hissi içindedirler. Bu nedenle beklentileri yüksektir. Hak ettiğinin kendisine verilmediği ya da verilmeyeceğini düşündüklerinde üsteleyici davranışlar gösterirler.

Paranoid üsteleyici: Paranoid kişilik yapısına sahip olanlar kolayca aldatılacağ1, kandırılacağ1 ya da bir kötülüğe maruz kalacakları düşüncelerine kapılırlar. Böyle bir durumda Paranoid kişilik yap1sına sahip olanlar gerekli hizmeti alamadığ1nı düşünerek üsteleyici davranış sergilerler. Bazen de gereksiz bazı işlem ve tetkiklerin yapıldığı kuşkusu içinde doktorlarla çatışabilirler.

Bağımlı üsteleyici: Bağımlı kişilik yapısına sahip insanlar kendisi ile ilgili her türlü kararın bir başkası tarafından alınması beklentisi içindedirler. $\mathrm{Bu}$ beklentileri ve psikolojik gereksinimlerinin karşılanacağı konusunda güvence arayışları üsteleyici davranmalarını neden olur.

Antisosyal üsteleyici: Antisosyal kişilik (psikopat, sosyopat) yapisina sahip insanlar bencilce isteklerinin en k1sa sürede yerine getirilmesi beklentisi içindedirler. Bütün işlerini kisa yoldan ve kestirmeden halletmek için üsteleyici davranış gösterebilirler

\section{Üsteleyici Hastanın Doktorda Yarattığı Duygu ve Düşünceler}

Üsteleyici bir hasta ile karşılaştığında doktorların öfke, kayg1, utanç, suçluluk, yetersizlik, belirsizlik, mağlubiyet hissi, umutsuzluk, hayal kirıklığ1, bıkkınlık, tükenmişlik ve çaresizlik gibi duygu ve düşünceler yaşadıkları görülmektedir. Bunlardan hangisini ne şiddette yaşayacağını büyük oranda doktorun kişilik yap1sı ve hasta-doktor ilişkisine bakış açısı belirler. Hastanın davranışlarının etkisi olmakla birlikte hangi duygunun ne şiddette yaşanacağında doktorun iç dünyasında etkinleşenler daha belirleyici olmaktadır.

Doktorun üsteleyici bir hasta ile karşılaştı̆̆ında yaşayacağ1 duyguyu belirleyen en önemli etmenlerden birisi de hastanın üsteleyici davranışları ile ilgili doktorların alg1larıdır. Örneğin hastanın davranışını 'keyfinden' ya da doktora 'kendisine bakmakla yükümlü bir kişi' olarak baktığ1 için öyle davranıyor yaklaşımı içinde olan doktor doğal olarak öfkeyi daha şiddetli yaşar.

Aşağıda zor hasta ile karşılaştığında doktorun yaşadığı duyguları etkileyen bazı kişilik özellikleri verilmiştir:

İnatçılık: İnatçı iki insan arasında bir inatlaşma başladığında bu çekişme çoğu zaman bitmez. Kişilik yapısında inatçılık olan bir doktor (örneğin obsesif kompulsif kişilik) bu kişilik özelliği nedeniyle sonu olmayan ya da gereksiz dayatmalarda bulunabilir.

Narsistik incinme: Her insanda sevilme, beğenilme, önemsenme ve takdir edilme gibi narsistik gereksinimler doğal olarak bulunur. Bu gereksinimler karşılanmadı̆̆ında da her insan değişen şiddetlerde olmak üzere narsistik incinme (üzüntü, öfkelenme vb) yaşar. Hastalar üsteleyici davranış gösterdiğinde doktorda 'yetersiz görüldüğü' ve 'kendini yetersiz görme' gibi hisler canlaniyorsa bunlar narsistik incinmenin göstergeleridir. Narsistik incinme yaşayan doktorda hastadan duygusal olarak uzaklaşma, hastay1 ret etme, hastaya öfkelenme gibi psikolojik tepkiler çıkabilir. Doktorda narsistik kişilik örgütlenmesi söz konusu olduğunda bu tepkiler daha şiddetli yaşanır.

'Hayır diyememe': Günlük yaşamında başkalarının isteklerini ret etmekte zorlanan doktorun bu yaklaşımı hasta-doktor ilişkisine de yansır. Hastanın taleplerini yerine getirmediğinde doktor rahatsız edici duygular yaşar. Hastanın 
taleplerini mutlaka yerine getirmesi gerekiyormuş hislerinin baskısı altında kalır. Canlanan bu duygular ile etik ilkeler arasında sıkışan doktor psikolojik olarak bunalır.

İşine karışıldığı duygusu: Kendisini alanında otorite olarak gören doktor, hasta çeşitli isteklerde bulunduğunda 'işine karışıldığı', yetkinliğinin ve otoritesinin sorgulandığ hissine kapilabilir. Böyle bir durumda da üsteleyici davranış basit bir istek olmaktan çıkıp doktorun mesleki yeterliliğinin sorgulanmas1 anlamı kazanır ve doktorun tepkisel davranışlar göstermesine yol açabilir.

Çatışmaktan kaçınma: Doktorların bir kısmı da uğraşmaktansa hastanın isteklerini yerine getirmeyi yeğleyebilmektedir. Özellikle çatışmadan kaçınma eğilimi olan doktorlarda bu yaklaşım daha sık görülmektedir. Ancak her koşulda öncelikle hastanın isteklerinin riski, tehlikesi, zararı ve yasal sorun yaratabilecek nitelikleri dikkatli biçimde incelenmelidir.

Sağlık çalışanları arasında hasta-doktor ilişkisinde paternalistik yaklaşımın (10) yaygın biçimde benimsendiği görülmektedir. $\mathrm{Bu}$ da hastanın doktora kayıtsız koşulsuz itaatkâr davranması gerektiği beklentisi yaratmaktadır. Bu beklenti içinde olan doktorlar hastanın üsteleyici davranışlarını kendilerine meydan okunması olarak yorumlamakta ve tepkisel davranabilmektedirler.

\section{Üsteleyici Hasta ile Baş Etme}

Her üsteleyici hasta için geçerli olacak standart bir yaklaşımın uygulanmaya konması mümkün değildir. Ancak tüm zor hastalar ile baş etmede olduğu gibi yol gösterici bazı ilkelerin dikkate alınmas1 gerekmektedir (Tablo 1). Üsteleyici hasta ile baş etmeye çalışan doktorlar kendi kişilik özelliklerini ve hastasının biyopsikososyal özelliklerini dikkate alarak hastasına yaklaşmalıdır.

Kendini tanıma: Zor hasta ile baş etme becerisini geliştirmek isteyen bir doktorun ilk yapması gereken kendisi hakkındaki farkındalık düzeyini arttırmaktır (9). Kendini tanıma, insanın kendisinde (bedeninde, iç dünyasında) var olanların, her türlü ilişkide nasıl davranacağının farkında olması ve bunları doğru değerlendirmesidir (11). Kendini tanıma; sorunlarla baş etme, strese katlanma ve duygu yönetimi gibi kişilerarası ilişkilere yön veren iletişim becerilerinin yeterliliğinin farkında olmayı da içerir.

Üsteleyici bir hasta ile karşılaşmak doktorda doğal olarak (bazen baş edilmesi güç düzeyde) çeşitli duyguları canlandırır. Doktor yaşadığı duygular ve bu duyguların kendisini nasıl yönlendirdiği konusunda farkındalık kazanmalıdır. Farkındalık kazanmasına karşın hastaların üsteleyici davranışları ile baş edemeyen ve bu nedenle psikolojik olarak tükenen ya da hastalardan duygusal olarak uzaklaşan doktorlar profesyonel yardım almayı düşünmelidir.

Hasta-doktor ilişkisine bakış açısı: Doktor, hastadoktor ilişkisine bakış açısını gözden geçirerek bakış açısının hastayla olan ilişkisini nasıl etkilediğini belirlemelidir. Geleneksel (paternalistik) yaklaşıma göre hasta-doktor ilişkisinde belirleyici olan doktordur. Hastanın doktorun dediklerini kayıtsız koşulsuz kabullenmesi, sorgulamaması beklenir (10). Geleneksel (paternalistik) doktor-hasta ilişkisini benimseyen doktor üsteleyici davranışlarda bulunan hasta karşısında şaşkına dönecek ve büyük olasılıkla hastaya reddedici davranacaktır.

Eşduyumsal anlayış: Eşduyumsal anlayış hastanın üsteleyici davranışının altta yatan nedenlerini görebilmeyi sağlar. Hastasını biyopsikososyal bütünlük içinde ele alamayan ve hastalarının psikolojik ve sosyal sorunlarını görmeyen ya da göz ard1 eden doktorların üsteleyici hastalara tepkisel olma olasılıkları daha yüksektir. $\mathrm{Bu}$ nedenle eşduyumsal anlama becerilerini geliştirmeleri gerekmektedir.

Etkileşimi değerlendirebilme: Her türlü kişilerarası iletişimde olduğu gibi hasta-doktor ilişkisinde de hasta doktoru, doktor da hastay1 etkiler. Doktor açısıyla bakıldığında etkileşimin önemli iki yönü vardır. İlki hastanın davranışlarının doktor üzerindeki etkisi; ikincisi ise doktorun söylediklerinin, ses tonunun, yüz ifadesinin, duruşunun ve el-kol hareketlerinin hastayı etkileyebildiğidir.

İletişim ve ilişkiyi yönetme: Kendini iyi tanıyan, hastasını eşduyumsal anlayışla değerlendirebilen ve hasta-doktor ilişkisinde karşılıklı etkileşimi görebilen doktorlar ilişkide yaşananları daha doğru değerlendirir. $\mathrm{Bu}$ da iletişim ve ilişkiyi istenen yönde sürdürebilme şansı verir. Üsteleyici bir hasta ile karşıllaştı̆̆ında ilişkiyi yönetmek, doktorun tepkisel olmadan hasta için en yararlı olacak şekilde davranabilmesi anlamına gelmektedir.

Hizmet sunum değişikliği: Hizmet sunum değişikliği ile üsteleyici hastaların üsteleyici davranışlarını azaltmak mümkündür. Butik hastanelerde pazarlama stratejilerini inceleyen bir yazıda butik sağlık sunumunun en iyisinin bedelini ödeyebilecek az sayıda talepkâr bireye yönelik olduğu ileri sürülmektedir (12). Ancak sağllk hizmeti sunumunun tümüyle hasta ve yakınlarının isteklerine göre belirlenmesi düşünülemez. 
Tablo 1. Üsteleyici hastalar ile baş etmede kullanışlı öneriler

- Doktor hastanın davranışlarını kişiselleştirmemeli.

- Doktor tepkisel davranmaktan kaçınmalı, davranışını etkileyecek düzeyde (örneğin öfke) duygu yaşadığında anında tepki göstermemeli.

- Doktor iletişimin yalnız kullanılan sözcüklerden ibaret olmadığını, ses tonunun ve beden dilinin hastayı nasıl etkile(yebil)diğini dikkate almalı.

- Açık uçlu, yargılamayan, suçlamayan, değer verildiği hissi yaratan sorularla hastanın derdini daha iyi anlatmasını sağlamalı

- Doktor o gün, o saatlerde ve o an yaşadığı duyguların farkında olmalı. (Önemli bir kısmı karşısındaki üsteleyici hasta ile ilgisi olmayan bu duyguların tahammül gücünü ve davranışlarını etkileyebileceğini unutmamali.)

- Hastanın kendisine güvenmediği hissine kapılması birçok doktorda rahatsız edici duygular yaratır. Doktor bu duygularından etkileniyorsa bunlarla baş etmenin yollarını bulmalı.

- Hastanın davranışını etkileyen etmenleri belirlemeye çalışmalı. (Geçmiş deneyimler, bilgi düzeyi, yanlış bilinenler, güncel sorunlar, kişilik yapısı, ruhsal rahatsızlıklar hastanın davranışını etkileyebilir.)

- Hastanın beklentilerini öğrenmeli. [Bazı hastalar açıcça söylemeseler bile kafalarında belirledikleri belli bir incelemenin (MR gibi) yapilmasını istiyor olabilirler. Hastaneye yatma, parenteral tedavi uygulanması gibi beklentileri de olabilir. Doktorun hastaya açık ve suçlayıcı tarzda olmayan kibar bir şekilde kendisinden ne beklediğini sorması hastanın beklentilerinin net bir şekilde anlaşılmasını sağlayabilir.]

- Hastanın hastalık rolü ile ne derece özdeşleştiğini belirlemeli. [Bazı hastalar hasta olduklarında çevrelerindeki insanlardan gördükleri ilgiyi (çoğu zaman bilinçdışı) sürdürmek için sürekli çeşitli yakınmalar getirirler.]

- Doğru tanı konduğuna dair hastanın kaygılarını gidermeli.

- Hastanın kaygıları ve kuşkuları yersiz bile olsa yargılamadan değerlendirmeli.

- İzlem, yapılacak incelemeler ve tedavi sürecini mümkün olduğunca hasta ile birlikte planlamalı.

- Hastanın tıbbi, etik ve yasal olmayan isteklerini yerine getirmemeli. (Kararlı fakat ret edici olmayan bir tavirla durumu hastaya bildirmeli.)

- Hastayı etkileyen her türlü duygunun (korku, kaygı) ifade edilmesini sağlamalı. İletişim ve ilişkiyi bozmayan duygu boşalımına (katarsis) izin vermeli.

- Hastanın bıktıran ve bezdiren istekleri doktorun hastadan uzaklaşmasına ve onun tıbbi ve psikolojik gereksinimlerini görememesine yol açabilir. Doktor bu tür durumlarda oluşan hastayn çok zorunlu olmadıkşa görmek istememe hissini aşmalı.

- Katı olmak ile kararlı olmak arasındaki fark irdelenmeli ve kararlı olunmalı

- Hastanın beklenti ve istekleri ögrenilerek ve dikkate alınarak sınırlar net olarak çizilmeli ve hastaya açıklanmalı.

- Üsteleyici hasta karşısında sürekli tepkisel davranış gösteren doktorlar davranışlarının altında yatan nedenleri daha iyi anlamak amaciyla profesyonel yardım almayı düşünmeli.

- Üsteleyici hastalar karşısında canlanan duygularla baş etmekte zorlanan, kendisini bozguna uğramış gibi hisseden ve bunları aşmakta çok zorlanan doktor bu konuda profesyonel yardım almayı düşünmeli.

\section{Kaynaklar}

1. Akgün-Çıtak E, Avcı S, Basmacı Ö, Durukan İ. Bir Üniversite Hastanesinde Hemşirelerin "Zor Hasta" Olarak Tanımladıkları Hastalarla İletişim Davranışlarının İncelenmesi. Hemar-G 2011; 13(1): 35-44.
2. Özmen E, Taşkın EO. "Zor Hasta" ve HastaHekim İlişkisinde Yaşanan Güçlükler. STED 2012; 21(4): 250-257.

3. Çelik R, Erdem R. Hastanelerde huysuz hastaların görülme sıklığ ve hastane çalışanlarına etkisi. Hacettepe Sağlık İdaresi Dergisi 2014; 17(2): $77-$ 88. 
4. Back AL. The myth of the demanding patient. JAMA Oncology 2015; 1(1): 18-19.

5. Ries A (2017) Talepkar müşteriler. Capital 16.03.2017

https://www.capital.com.tr/yazarlar/alries/talepkar-musteriler (E.T. 03.02.2018)

6. Schafer S, Nowlis DP. Personality disorders among difficult patients. Arch Fam Med 1998; 7(2): 126-129.

7. Gökçe O, Bulduklu Y. Sağlık hizmetlerinin sunumunda "müşteri hasta" ve etik sorunlar. Sosyal Ekonomik Araştırmalar Dergisi 2015; 15(29): 38-61.

8. Tar1 B, Yavuzer R. Hasta-hastane-hekim ilişkisinde tüketim dinamikleri ve tüketici kimliği ile hasta. Gazi Medical Journal 2007; 18(4): $145-$ 150.

9. Cannarella Lorenzetti R, Jacques CH Donovan C, Cottrell S, Buck J. Managing difficult encounters: understanding physician, patient, and situational factors. Am Fam Physician 2013; 87(6): 419-425.

10. Emanuel EJ, Emanuel LL. Four models of the physician-patient relationship JAMA 1992; 267(16): 2221-2226.

11. Özmen E. Hayatın içinde iletişim. CBU-SBED 2016; 3(2): 229-231.

12. Salman AN, Uydac1 M. Butik hastanelerde pazarlama stratejileri. Öneri Dergisi 2012; 9(35): 45-50. 